\title{
Challenges Encountered by Community Colleges at Shaqra University in Saudi Arabia: A Documentary Analysis
}

\section{Fahad Mohammed Alabdulmenem ${ }^{1}$}

\begin{abstract}
The principal aim of this study is to investigate to what extent the four community colleges operating under the jurisdiction of Shaqra University: Shaqra, Adduwadimi, Huraymila, and Alquwayiyah, meet the needs of Saudi Arabian society. The research method was a qualitative documentary analysis, which involved examining and interpreting official documents. The following are the primary findings of the study:(a) enrollments at the four colleges have fluctuated over the past 3 years (2012-2014); (b) the number of graduates from the four community colleges has steadily decreased, resulting in an abnormally low graduation rate overall; (c) the faculty to student ratios at the community colleges are typically small; and (d) there was a policy of continuous hiring of additional administrators and technicians between 2012 and 2014, with the result that the ratio of administrators and technicians to enrollees has become bloated. Consequently, the continued existence of these community colleges hangs-in-the-balance, and the concerned authorities need to seek urgent resolution to this problem to avoid huge financial losses and wastage on the part of the government. To resolve the on-going problems, the researcher recommends that the four community colleges at Shaqra University be just combined into two, and if necessity requires, retrenchment of faculty and administrators is conducted to achieve the ideal faculty to student ratio and administrator to student ratio.
\end{abstract}

${ }^{1} \mathrm{PhD}$ and Associate Professor of Educational Administration and Planning, Education and Psychology Department, Science and Human Studies College, at Huraimila, Shaqra University. Email: alabdulmenemfahad@gmail.com 
Keywords: Community college; Shaqra University; student to faculty ratio; over-bloated; Saudi Arabia; Documentary Analysis

\section{Introduction}

After several decades of growth, community colleges are now entering a particularly challenging phase. This has raised the question of whether they are still relevant or if it would be better to close them down for practical reasons.In general, closure is viewed as a last resort when all other possible solutions have been explored. In Saudi Arabia, for instance, community colleges are increasingly encountering multiple problems as they strive to increase the number of enrollments and produce adequate numbers of graduates annually. These problems are further exacerbated by the reality that when college graduates apply for jobs the majority are not hired because of strong competition, as employers believe that graduates from community colleges are not on a par with those from the universities. This paper aims to investigate and analyze the status of community colleges, in order to explore to what extent these institutions meet the needs of Saudi Arabian society.

This study has the following specific objectives:

1) Review prominent contemporary international experiences of community colleges, particularly with regard to increasing the enrollment of students;

2) Determine the statistics for the enrollment of students at different community colleges in Shaqra University;

3) Determine the factors or reasons behind the reluctance of some students to enroll in a particular discipline; and

4) Offer best possible solutions to the problems identified, to benefit the community college system in Shaqra University.

The importance of this study is to provide detailed information about the current situation experienced by Shaqra community colleges in the Kingdom of Saudi Arabia, and to offer the best possible solutions to these problems. In this way, it will contribute to reducing educational wastage rates. Furthermore, this study aims also to serve as a guide for educational economists, sociologists, and industrialists who are striving to plan to improve the work force and society as a whole. Both technical junior colleges and teacher training junior colleges are regarded as exemplars of the development of Saudi Arabian citizens who wish 
to serve productively as technicians and qualified teachers (Al-Ghandi, 1984). The scope of this study was limited to four community colleges under the auspices of Shaqra University. The information gathered was mainly based on government documents, which were subjected to different statistical analyses to extract comprehensive findings.

\section{The Community College System}

The fundamental concept of the community college developed during the $20^{\text {th }}$ century in the United States (U.S.), aiming to extend the opportunities of higher education to all its citizens (Cohen \& Brawer, 2013). Colleges were designed to have an "open door" admissions policy; accepting all high school graduates and older adults and offering comprehensive educational programs to cater for a variety of learning needs. Although every community college has its own philosophy, goals, and institutional objectives according to its perceived mission within the local community, common characteristics continue to define the majority of community colleges. Educational programs at community colleges usually include one or two-year courses in technical or semiprofessional fields, with an option to proceed subsequently to a college or university. Most two-year programs lead to an Associate degree. In addition, a wide variety of courses, seminars, and short programs, both credit and noncredit, are also offered for part-time students during daytime or evening hours. In fact, the word "community" implies more than simply educational offerings, suggesting these colleges serve other needs of the wider community, such as through the provision of counselling, job placement, cultural programming, participation in the governance of institutions, etc.

\section{Philosophy of a Community College}

The distinguishing feature of a community college is its open-door policy on admissions, as stated above, which mean everyone is welcome to enroll, regardless of economic status, academic performance at high school, age, race, gender, religion, or membership of a minority or indigenous group (Cohen, 2013). However, despite this policy, community colleges are expected to strive to maintain standards to insure the employability of their graduates, and guarantee the credits they bestow to universities.

Community colleges primarily function to enhance human potential, providing a college for people. Indeed, a comprehensive community college 
should ideally guarantee the following: (1) responsiveness to local needs; (2) equal stature with other academic institutions; (3) continuous financial support; (4) connections with government agencies; and (5) research and development to meet future needs (Cohen et al, 2013) .Moreover, a comprehensive community college should be characteristically democratic, understanding, caring, approving, supporting, loving and non-judgmental. This then helps students to achieve a mature self-hood, self-understanding, and articulate an awareness of their purpose in life, and sensitivity to others and the environment.

Finally, other salient features of comprehensive community colleges are that they should offer comprehensive curricula, foster innovativeness and creativity; provide education at low cost if not entirely free, while also operating accessible and flexible timetables.

\section{The American Community College}

The importance of community colleges in the American educational structure can be summarized as "the most dynamic existing higher education institutions today" (Cohen \& Brawer, 2013). Community colleges are integral to the American higher education setting, and are viewed as leaders in terms of creative, flexible, and individualized approaches to the learning process. Community colleges are the major body responsible for placing college opportunities within the reach of aspiring students (McVeigh, 2007). They also play a key role in democratic systems of higher education that recognize individual differences and the social worth of individuals possessing a wide range of interests, capacities, aptitudes, and types of intelligence (Franco, 2009). According to Robert Palinchak (1973), community colleges aim to serve a student base that extends beyond the academically gifted. Their aim is to provide educational services to everyone, operating in the public interest according to a philosophy that prioritizes equal access. Whatever form a community college takes its primary purpose is to deliver educational services to the entire community, and for this reason, these colleges support a variety of functions and programs.

The value of community colleges to the American economy has become famous internationally, andas a result, other countries are looking to the U.S. for models of open access institutions, which are widely considered the engines of the middle class (Davis \& Wessel, 1998). 


\section{Community Colleges: The Chinese Experience}

In China, community colleges have become the driving force of the country's transition from a planned to a market economy. In Mainland China, every province has its own community college with highly specialized training programs and curricula on textiles, railroads, postal service, energy resources, military, forestry, etc. (Yung, 2002). Community colleges in Hong Kong and Mainland China have taken a multinational approach toward studying and adopting innovations from other countries. Certainly, Hong Kong has come to depend heavily on the American community college model (Yung, 2002), while Mainland China, although it has also adapted the U.S. model, has applied it principally to develop post-secondary vocational-technical aspects of education (Raby \& Valeau, 2009). Initially, Hong Kong community colleges were introduced to weather a financial crisis in tertiary education; however, they later became major components of the tertiary education system (Lee \& Young, 2003). In the case of Mainland China, examples of notable community colleges are Haidian University in Beijing, Sanda College in Shanghai's Pudong district, and Xian Translation College in Xian. Although most community colleges are government funded, a growing number rely on private financing (Lee \& Young, 2003).

However, as jobs are no longer guaranteed upon graduation from vocational technical education institutions, as they were under the centrally planned economy, a crisis of sorts arose as market demand for general higher education increased (Lee \& Young, 2003). This led China to explore other possible models to manage its post-secondary vocational and technical education. Among the models that gained currency were those applied in the successful market economies of Germany, Japan, England, Australia, Korea, and Canada. The noted success of the German and Japanese models of postsecondary vocational and technical education came to inform China's approach to reform its own system (Yung, 2002).

Mainland China's community college system is distinct in several ways from the American model it was adapted from. For example, it focuses less on the ideology of democracy, and ignores the possibility of Associate degrees, and pathways to four-year colleges and universities. 


\section{Major Causes of Drop-outs from Community Colleges}

One reason for dropout rates is the inefficient and ineffective counseling offered by colleges, probably as they struggle to service the large student population (Agodini \& Dynarski, 2004). Some students discontinue their studies because of an inability to adjust to the college environment, or because they experience culture shock when moving from a rural area to a big city, or from countries with different cultures. However, a major reason for learners' dropping out is their lack of skill in certain academic areas, such as mathematics, and language or reading. Finally, some students drop out because they are working either full time or part-time while studying and fail to balance their studies effectively as their work schedules sometimes conflict with their school schedules. To assist this group it would be helpful for the college to provide evening classes and flexible teaching schedules (Agodini \& Dynarski, 2004).

\section{Challenges Community Colleges Face Today}

In a study conducted by Levine et al. (2004), six "experts" including Presidents, Chancellors, and Professors at two-year and four-year institutions, were asked to identify the most pressing issues faced by community colleges. They identified the following challenges: (1) meeting the needs of a changing society; (2) choosing between competing agendas; (3) staying focused on suitable missions; (4) meeting the needs of increasing student enrollments with less funding; (5) hiring and motivating employees; and (6) dealing with fragmentation, isolation, and divisiveness.

In Saudi Arabia, the problems encountered by community colleges, as mentioned in an open interview conducted for this research were: (1) lack of publicity and knowledge about colleges; (2) difficulties with registration; (3) prospective students outside Jeddah or big cities facing housing and transportation problems; (4) lack of centralization of buildings, which is more of a barrier because of the high temperatures; and (5) staff scarcity.

Additional pressing problems that community colleges in Saudi Arabia in particular face, are fallingenrollment due to the preference among students to enrollat universities. However, a further serious problem is the inability of community college graduates to find jobs. This is perhaps due to the high levels of competition and erroneous beliefs held by employers, who think that those 
graduates from community college are not as high quality or as qualified as their university counterparts (Cristobal \& Nahra, 2016).

\section{Typical Characteristics of Students in a Community College}

Community college students are usually much older than their university counterparts. "About sixty percent of adults (25 and older) are enrolled in twoyear community colleges" (Aslanian, 2001, p. 29). Community colleges also have a higher percentage of minority students enrolled. Cohen and Brawer (2013) state that this is due to the ease of access, low tuition requirements (or none at all), and the open-door policy of community colleges. Students from ethnic minorities also frequently enroll on a part-time basis because of economic difficulties. Unfortunately, because of their open-door policy, community colleges also willingly enroll underprepared students, explaining ninety-five percent of the remedial education classes. In addition, twenty-nine percent of all students entering college are underprepared in at least one of the basic skills areas; i.e. reading, writing, and mathematics (McCabe, 2000, p. 4).

\section{Brief Background to Community Colleges in Saudi Arabia}

Saudi Arabia and other countries in the Middle East, such as Oman and Jordan, have adopted the community college system from America. In Saudi Arabia, attendance at a community college is one of the options offered to high school graduates as an alternative to undergraduate programs or four-year college courses. Community college programs usually last two years, and are either: (a) occupational programs; and (b) transfer programs. Occupational programs aim to produce graduates prepared to join the work force upon graduation. Whereas, transfer programs qualify students to undertake further study at a university or college. (Ministry of Higher Education, Saudi Arabia (MOHE), 2016)

Features of community colleges include comprehensiveness and flexibility, to align with the needs of individuals and the whole of society. The main objectives of a community college are as follows: (a) to provide a variety of programs, especially those needed to serve the labor market in the local community; and (b) to accommodate high school graduates who have inclinations towards the sciences and who intend to proceed to a university level education.Students in these community colleges are classified as either: (a) regular students, also known as full-time students; (b) external students, or parttime affiliated students; and (c) parallel education students who attend evening 
classes that are usually separate from the formal educational structures (Ministry of Higher Education, Saudi Arabia, MOHE, 2016).

The community colleges examined in this study are Shaqra Community College, Huraymila Community College, Alquwayiyah Community College, and Adduwadimi Community College. All these community colleges are under the jurisdiction of Shaqra University, which was established as a result of a decree by the Custodian of the Two Holy Mosques, King Abdullah Bin Abdul Aziz Al-Saud and the Prime Minister and Chairman of Higher Education on Ramadan $3^{\text {rd }}, 1430-24^{\text {th }}$ of August, 2009.

\section{Huraymila Community College}

Huraymila College was established by order of the King of Saudi Arabia, Decree No. 5995 dated 07/03/1423 AH. Its aims were to serve the people of the province and to reduce the demand for programs at higher education institutions in Riyadh City. Admission to the community college was open to all high school graduates, and the academic programs offered are divided into Transitional Programs and Qualifying Programs. From Transitional Programs, students qualify to proceed to a college or university in accordance with standards set by the community college, but the program does not earn them a degree. By contrast, the Qualifying Program ends with a degree called an "Associate Degree". The student must complete 64 credit units within the allotted two-year period. Courses available are: banking, business management, executive secretarial course, human resource management, accounting, computer science, and the humanities. (Ministry of Higher Education, Saudi Arabia, MOHE, 2016)

\section{Alquwayiyah Community College}

This community college was established by resolution Sami No. 10093 dated $21 / 11 / 1428$. It offers programs such as computer science, accounting and financial management. These courses take two years to complete. Other courses are also offered, which take two-and-half years to finish; these are banking business and insurance business. All the mentioned courses earn students an “Associate Degree" (Al-Ghandi, 1984). 


\section{The Present Study}

The aim of this study is to understand the major challenges and opportunities facing community colleges in the Kingdom of Saudi Arabia, and document analysis was selected as the research method. Document analysis is a descriptive research method, taking the form of a"systematic procedure for reviewing and evaluating documents" in order to elicit meaning, gain understanding, and develop empirical knowledge (Bowen, 2009). The official documents subjected to statistical analysis were obtained from public government agencies and concerned school institutions. The study also involved gathering and selecting data via the internet, particularly from the Education Resources Information Center, the ERIC website. (Ministry of Education: Education Statistics Center, 2016).

\section{Results and Discussions}

\section{Statistical Summary of Enrollments at the Four Community Colleges}

Table 1 displays the enrollment figures for the four community colleges from A.Y. 2012-2014. As apparent from the table, there was an increase in enrollments for the years 2012 and 2013 at both Shaqra Community College (68\%) and Adduwadimi Community College (36\%). In contrast, both Huraymila and Alquwayiyah community colleges witnessed a 15\% and 8\% drop in enrollment, respectively. For the AY 2013-2014, Shaqra Community College posted a 33\% decrease in its enrollment. Similarly, Adduwadimi Community College posted a $49 \%$ fall. On the other hand, there were noted increased in enrollments for Huraymila Community College, at $97 \%$, and a $19 \%$ increase for Alquwayiyah Community College. Based on this trend, it can be surmised that enrollments at the colleges fluctuates with minimal increases across a three-year period. Random interviews with some students revealed this was because many doubt whether they can find jobs after graduation, and even whether they will be able to proceed to earn a university degree. The community colleges have not satisfactorily reassured them about these concerns. 
Table 1 Enrollment at the four community colleges from A.Y. 2012-2014

\begin{tabular}{|c|c|c|c|c|c|}
\hline 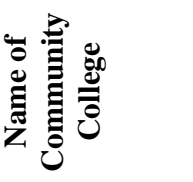 & 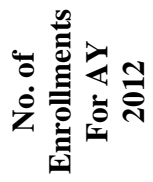 & 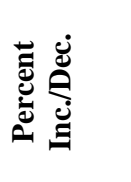 & 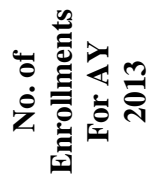 & 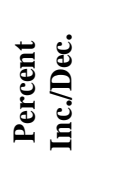 & 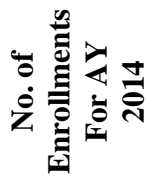 \\
\hline Shaqra & 133 & $68 \%$ inc. & 224 & $33 \%$ dec. & 150 \\
\hline Adduwadimi & 140 & $36 \%$ inc. & 190 & $49 \%$ dec. & 97 \\
\hline Huraymila & 375 & $15 \%$ dec. & 319 & $97 \%$ inc. & 627 \\
\hline Alquwayiyah & 429 & $8 \%$ dec. & 394 & $19 \%$ inc. & 468 \\
\hline
\end{tabular}

Source: Ministry of Education: Education Statistics Center (2016).

Figure 1 provides a statistical summary of students at Shaqra University, in terms of the numbers enrolled for AY 2012-2013.It is apparent from the graph that a huge proportion of Shaqra University's enrollments are for those seeking Bachelor's degrees (91\%), followed by those seeking Associate degrees (5\%), and Graduate degrees (4\%). From the perspective of the community colleges (Associate degrees), enrollments are clearly far fewer than those for Bachelor's degrees and only a little higher than those for Graduate degrees.

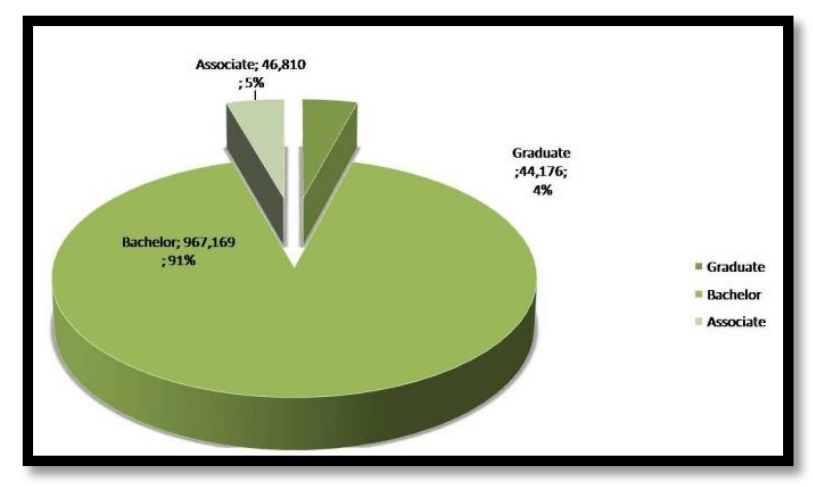

Figure 1 Statistical summary of students at Shaqra University in terms of number of enrollments AY 2012-2013

Source: Ministry of Education: Education Statistics Center (2016). 


\section{Statistical Summary of the New Entrants to the Four Community Colleges}

Table 2 shows the percentage increase/decrease in the number of new entrants to the four community colleges studied. New entrants refers to new enrollees or first time attendees atcollege.For the year 2012-2013, the majority of community colleges saw an increase in the number of new entrants, with the exception of Huraymila community college, which experienced a decrease of $39 \%$ in the number of new entrants. For the years 2013-2014, the number of new entrants at both Shaqra and Adduwadimi community colleges fell. In contrast, both Huraymila and Alquwayiyah had more new entrants than previously. Interestingly, Huraymila community college witnessed a more than four-fold increase in the number of new entrants during this two-year period. Thus, overall, the majority of the community colleges showed a slight increasing trend in the number of new entrants for the 3 year-period.

Table 2 Percentage increase/decrease in the number of new entrants at the four community colleges, 2012-2014

\begin{tabular}{|c|c|c|c|c|c|}
\hline 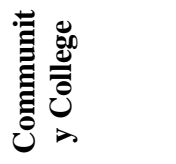 & 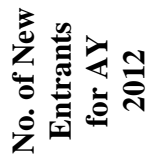 & 荖 & 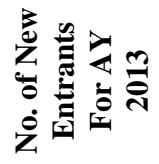 & 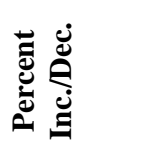 & 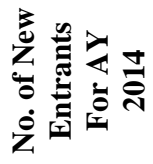 \\
\hline Shaqra & 56 & $146 \%$ inc. & 138 & $85 \%$ dec. & 21 \\
\hline Adduwadimi & 59 & $85 \%$ inc. & 109 & $62 \%$ dec. & 41 \\
\hline Huraymila & 117 & $39 \%$ dec. & 71 & $458 \%$ inc. & 396 \\
\hline $\begin{array}{c}\text { Alquwayiya } \\
\mathrm{h}\end{array}$ & 80 & $65 \%$ inc. & 132 & $130 \%$ inc. & 304 \\
\hline
\end{tabular}

Source: Ministry of Education: Education Statistics Center (2016).

Figure 2 provides a statistical summary of students at Shaqra University, in terms of number of new entrants AY 2012-2013. As can be seen from the graph, a great majority of new entrants were enrolling for Bachelor's degree (89\%), followed by those seeking Graduate degrees (6\%), and Associate degrees (5\%). It can also be inferred from the graph that Associate degree seekers comprise the smallest group of new entrants to programs offered by Shaqra University. 


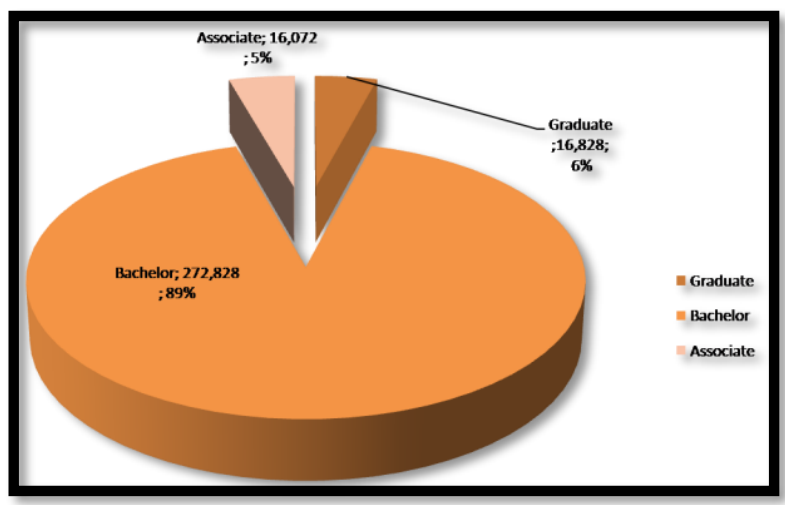

Figure 2 Statistical Summary of students at Shaqra University in terms of number of new entrants AY 2012-2013

Source: Ministry of Education: Education Statistics Center (2016).

\section{Statistical Summary of the Graduates at the Four Community Colleges}

Table 3 depicts the number of student graduates by major and gender at the four different colleges for the year 2013. As columns 2 and 3 show, the computer science major had the highest number of graduates (98), followed by Banking Business (59), Human Resources (41), Accounting (36), Marketing and Financial (both have 13), Insurance (12), and finally the lowest number was for Insurance (3). Columns 4 and 5 show distribution by gender for different courses, and these columns also show courses such as Marketing (100\%) and Computer Science $(74 \%)$ were dominated by males. Meanwhile, courses including Financial Management (100\%), Accounting (64\%), Insurance (100\%), Human Resources (73\%), and Business Banking (85\%) were dominated by females. In general, females were the dominant gender across the different courses offered by all four community colleges. 

2013

Table 3 Number of graduates by major and gender at the four different colleges,

\begin{tabular}{ccccc}
\hline $\begin{array}{c}\text { Community } \\
\text { College }\end{array}$ & Major & $\begin{array}{c}\text { No. of } \\
\text { Students }\end{array}$ & Male & Female \\
\hline Shaqra & Marketing & 13 & 13 & $0(0 \%)$ \\
& Computer Science & 98 & $72(74 \%)$ & $26(26 \%)$ \\
Alquwayiyah & Financial & 13 & $0(0 \%)$ & $13(100 \%)$ \\
Alquwayiyah & management & & & \\
& Accounting & 36 & $13(36 \%)$ & $23(64 \%)$ \\
Alquwayiyah & Insurance & 12 & $0(0 \%)$ & $12(100 \%)$ \\
Alquwayiyah & Human Resources & 41 & $11(27 \%)$ & $30(73 \%)$ \\
Huraymila & Banking Business & 59 & $9(15 \%)$ & $50(85 \%)$ \\
Huraymila & Insurance & 3 & $0(0 \%)$ & $3(100 \%)$ \\
Huraymila & S &
\end{tabular}

Source: Ministry of Education: Education Statistics Center (2016).

Figure 3 shows a statistical summary of students at Shaqra University for the Academic Year 2012-2013. From this graph, it is apparent that a great majority of graduates gained Bachelor'sdegrees (81\%); followed by Associate (13\%), and Graduate $(6 \%)$ degrees. Based on the graph, it can also be inferred that the number of graduates gaining Associate degrees from the four community colleges correspondedto little more than $10 \%$ of the total number of graduates.

Table 4 shows a percentage increase/decrease in the number of graduates at the four community colleges from 2012-2014. As can be observed for 2012 and 2013, in general there were a greater number of graduates from the majority of the colleges for that year, except for Adduwadimi community college, which posted a reduced number of graduates. Ironically, for the academic years 2013 and 2014, the remaining community colleges witnessed a decrease in the number of graduates, while Alquwayiyah community college saw a $92 \%$ increase.

Table 4 Percentage increase/decrease in the number of graduates from the four community colleges, 2012-2014

\begin{tabular}{cccccc}
\hline $\begin{array}{c}\text { Name of } \\
\text { Community } \\
\text { College }\end{array}$ & $\begin{array}{c}\text { No. of } \\
\text { Graduates } \\
\text { For AY } \\
\mathbf{2 0 1 2}\end{array}$ & $\begin{array}{c}\text { Percent } \\
\text { Inc./Dec. }\end{array}$ & $\begin{array}{c}\text { No. of } \\
\text { Graduates } \\
\text { For AY } \\
\mathbf{2 0 1 3}\end{array}$ & $\begin{array}{c}\text { Percent } \\
\text { Inc./Dec. }\end{array}$ & $\begin{array}{c}\text { No. of } \\
\text { Graduates } \\
\text { For AY } \\
\mathbf{2 0 1 4}\end{array}$ \\
\hline Shaqra & 20 & $355 \%$ inc. & 91 & $86 \%$ dec. & 13 \\
Adduwadimi & 18 & $17 \%$ dec. & 15 & $100 \%$ dec. & 0 \\
Huraymila & 143 & $43 \%$ inc. & 204 & $50 \%$ dec. & 103 \\
Alquwayiyah & 13 & $539 \%$ inc. & 83 & $92 \%$ inc. & 159 \\
\hline
\end{tabular}

Source: Ministry of Education: Education Statistics Center (2016). 
In general, however, table 4 shows a general decreasing trend in terms of the number of graduates over the three-year period. There are multiple possible reasons for this, and one possible obvious reason is that a general decrease in enrollmentat the four community colleges had been occurring for several years.

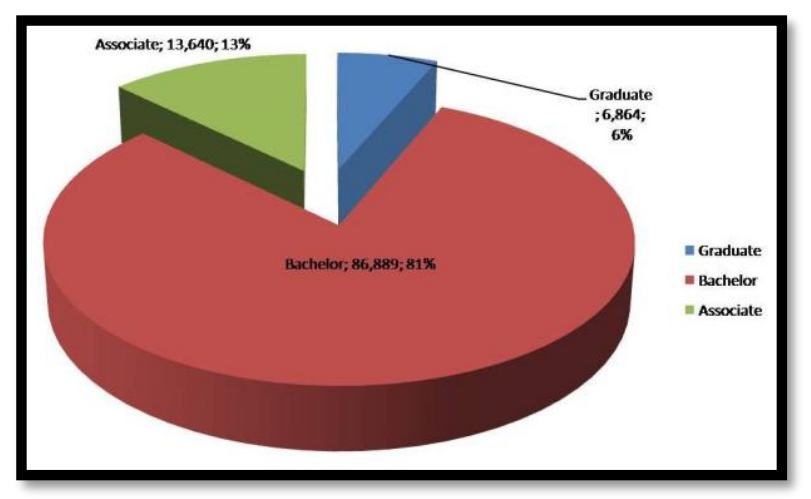

Figure 3 Statistical summary of students at Shaqra University by the number of graduates AY 2012-2013

Source: Ministry of Education: Education Statistics Center (2016).

Graduation rate is an indication of the success of a college student body's attainment of educational goals. It is also an evaluation criteria that can be applied determine the effectiveness of an educational institution. It is determined by dividing the total number of enrollments with the total number of graduates. Table 5 shows the graduation rate at the four community colleges. The assumption is that those who enrolled in 2012 would be expected to graduate in 2014, because it normally takes 2 years to complete an Associate degree course. As can be seen from the table, Alquwayiyah community college had the highest graduation rate at $37 \%$, followed by Huraymila community college at $28 \%$, then Shaqra community college at $10 \%$, and finally Adduwadimi community college with a $0 \%$ graduation rate. 
Table 5 Graduation rates at the four community colleges

\begin{tabular}{cccc}
\hline $\begin{array}{c}\text { Community } \\
\text { College }\end{array}$ & $\begin{array}{c}\text { No. of Enrollments } \\
\text { For AY 2012 }\end{array}$ & $\begin{array}{c}\text { No. of } \\
\text { Graduates } \\
\text { For AY 2014 }\end{array}$ & $\begin{array}{c}\text { Graduation } \\
\text { Rate }\end{array}$ \\
\hline Shaqra & 133 & 13 & $10 \%$ \\
Adduwadimi & 140 & 0 & $0 \%$ \\
Huraymila & 375 & 103 & $28 \%$ \\
Alquwayiyah & 429 & 159 & $37 \%$ \\
\hline
\end{tabular}

Source: Ministry of Education: Education Statistics Center (2016).

In general, the graduation rate at all four colleges was very low. In comparison, the College of William and Mary in the U.S. is ranked two in the world based on a $90 \%$ graduation rate (Mitchell, 2013). The low graduation rate at the four community colleges under review is indicative of certain problems they face. Earlier, it was mentioned that some students experienced uncertainty, possibly leading to the very low graduation rates. Some students, after enrolling at the college, might have later learned that they might not have a certain future after graduation leading them to simply stop their schooling. Another possible reason is that some might have failed in their academic subjects making them no longer eligible to enroll. This is possible, since most students who enter the college are actually ill-prepared academically or practically for college life, because of the policy of not enforcing entrance requirements at community colleges.

\section{Faculty Profile in the Four Community Colleges}

Table 6 shows the number of teaching staff at the four community colleges from 2012-2014. As can be noted, Shaqra community college more than doubled its 29 teaching staffbetween 2012 and 2013, and then increased slightly by a further two teachers between 2013 and 2014. Adduwadimi community had no teaching staff in 2012, but hired 35 teaching staff in 2013, and in 2014 increased its teaching staff by a further five. Huraymila had 38 teaching staff in 2012, but more than doubled that number in 2013; it retained this number of staff in 2014. Interestingly, Alquwayiyah community college had 64 teaching staff in 2012, but in 2013 it had zero. We therefore must ask: what happened to them? In 2014, the college registered 74 teaching staff. This is 10 higher than the number of teaching staff registered for 2012.

Figure 5 displays the faculty rank profile for the different community colleges, and as we can see a greater majority of the faculty hold the rank of 
lecturer (100), followed by Teaching Assistant (70), Assistant Professor (68), Associate Professor (8), Professor (5), and none are designated as teachers.

Table 6 Number of teaching staff at the four community colleges, 2012-2014

\begin{tabular}{cccc}
\hline $\begin{array}{c}\text { Name of } \\
\text { Community } \\
\text { College }\end{array}$ & $\begin{array}{c}\text { No. of Teaching } \\
\text { Staff } \\
\text { forAY 2012 }\end{array}$ & $\begin{array}{c}\text { No. of Teaching } \\
\text { Staff } \\
\text { forAY 2013 }\end{array}$ & $\begin{array}{c}\text { No. of Teaching } \\
\text { Staff } \\
\text { forAY 2014 }\end{array}$ \\
\hline Shaqra & 29 & 60 & 62 \\
Adduwadimi & 0 & 35 & 40 \\
Huraymila & 38 & 75 & 75 \\
Alquwayiyah & 64 & 0 & 74 \\
\hline
\end{tabular}

Source: Ministry of Education: Education Statistics Center (2016).

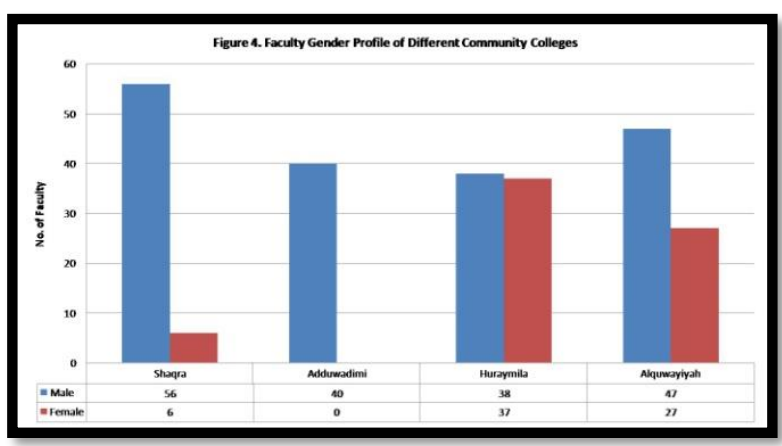

Figure 4 shows the faculty gender profiles for the different community colleges. As the graph shows, a majority of the faculty at all four community colleges are male.

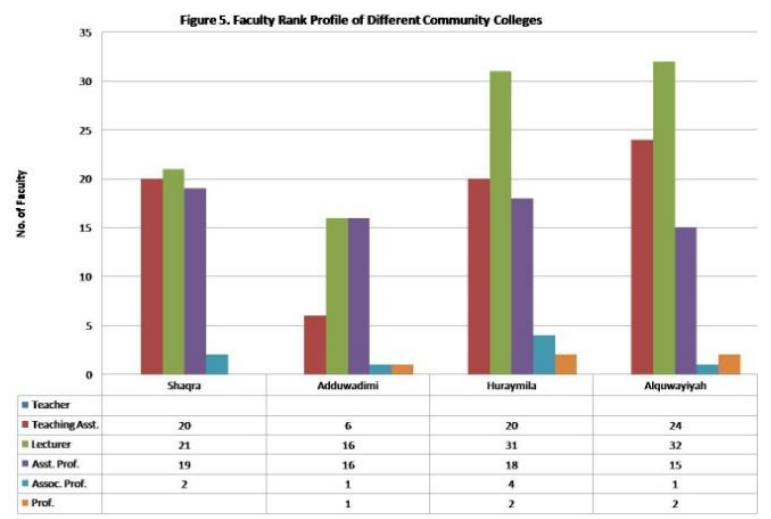

Source: Ministry of Education: Education Statistics Center (2016). 
Figure 6 presents the nationality profile for the faculty in the different colleges, and as we can see, a greater majority of the faculty are non-Saudis (134), compared to 117 for Saudi faculty members.

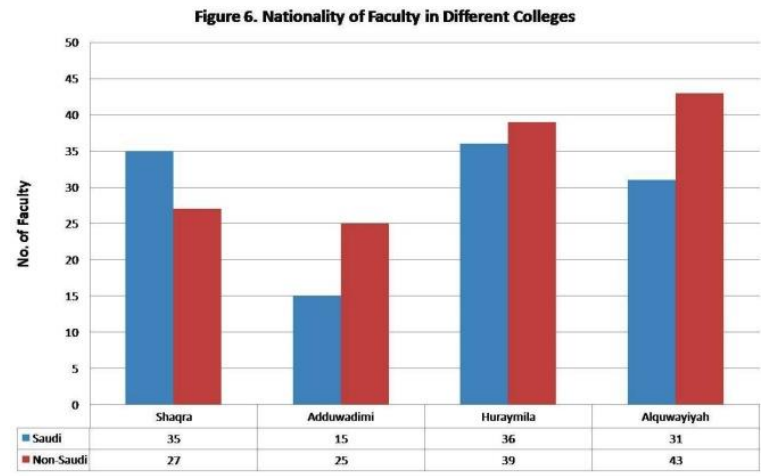

Source: Ministry of Education: Education Statistics Center (2016).

\section{Profile of Administrators and Technicians in the Four Community Colleges}

Table 7 shows the number of administrators and technicians at the four community colleges for the years 2012-2014. It illustrates that Shaqra community college had 27 administrators and technicians in 2012 but this number fell to only 10 administrators and technicians in 2013, and then by 2014 , there were 13 administrators and technicians. At Adduwadimi community college, a different trend emerged, as the number increased from 10 administrators and technicians in 2012to 43 (increased by more than four times) by 2013, increasing further to 49 in 2014. This data implies continual hiring of administrators and technicians between 2012 and 2014. A similar trend toward increasingthe number of administrators and technicians emerged at Huraymila and Alquwayiyah community colleges from 2012 to 2014.

Table 7 Number of administrators and technicians at the four community colleges, 2012-2014

\begin{tabular}{cccc}
\hline $\begin{array}{c}\text { Name of } \\
\text { Community } \\
\text { College }\end{array}$ & $\begin{array}{c}\text { No. of } \\
\text { Administrators and } \\
\text { Technicians for } \\
\text { AY 2012 }\end{array}$ & $\begin{array}{c}\text { No. of } \\
\text { Administrators } \\
\text { and Technicians } \\
\text { for }\end{array}$ & $\begin{array}{c}\text { No. of } \\
\text { Administrators } \\
\text { and Technicians } \\
\text { fy 2013 }\end{array}$ \\
\hline Shaqra & 27 & 10 & AY 2014 \\
Adduwadimi & 10 & 43 & 13 \\
Huraymila & 12 & 42 & 49 \\
Alquwayiyah & 11 & 30 & 48 \\
\hline
\end{tabular}

Source: Ministry of Education: Education Statistics Center (2016). 
Figure 7 reveals the professional qualifications of the administrators and technicians employed by the four community colleges; as can be seen in the graph, the majority are Bachelor's graduates (61), followed by others (48), and Diploma holders (37). None are graduates holding only high school diplomas, and none have Master's, or Doctorates.

Table 8 shows the ratio of teaching staff to enrollees and the ratio of administrators and technicians to enrollees. As can be seen, Shaqra, Huraymila, and Alquwayiyah all share the same ratio of 1:4 teaching staff against the number of enrollees, while Adduwadimi has a 1:5 ratio of teaching staff to enrollees. A recent study found that each faculty member at a typical Saudi university is offset by 15 male students and 26 female students, while the global average is 13 male students and 20 female students to every faculty member (MoHE Saudi Arabia, 2014). Thus, in general, these faculty member to student ratios at the community colleges under review are too small compared to even the top two colleges in the U.S.: William and Mary College, which have a ratio of 12:1. The implication is that the government is spending a lot of money paying for teaching staff who are responsible for an unusually small number of students.

Table 8 Ratio of teaching staff to enrollees and ratio of administrators and technicians to enrollees for AY 2013-2014

\begin{tabular}{lccccc}
\hline $\begin{array}{c}\text { Community } \\
\text { College }\end{array}$ & $\begin{array}{c}\text { No. of } \\
\text { Administrat } \\
\text { ors and } \\
\text { Technicians }\end{array}$ & $\begin{array}{c}\text { No. of } \\
\text { Enrollee } \\
\text { s }\end{array}$ & $\begin{array}{c}\text { No. of } \\
\text { Teachin } \\
\text { g Staff }\end{array}$ & $\begin{array}{c}\text { Ratio of } \\
\text { Teaching } \\
\text { Staff to } \\
\text { Enrollees }\end{array}$ & $\begin{array}{c}\text { Ratio of } \\
\text { Administr } \\
\text { ators \& } \\
\text { Technician } \\
\text { s to } \\
\text { Enrollees }\end{array}$ \\
\hline Shaqra & 10 & 224 & 60 & $1: 4$ & $1: 22$ \\
Adduwadimi & 43 & 190 & 35 & $1: 5$ & $1: 44$ \\
Huraymila & 42 & 319 & 75 & $1: 4$ & $1: 8$ \\
Alquwayiya & 30 & 394 & 89 & $1: 4$ & $1: 13$ \\
h & & & & & \\
\hline
\end{tabular}

Source: Ministry of Education: Education Statistics Center (2016).

Meanwhile, in terms of the ratio of administrators and technicians to enrollees (see table 8), the smallest ratio was 1:8 for Huraymila, followed by Alquwayiyah (1:13), Shaqra (1:22), and the largest was Adduwadimi (1:44). In a recent study conducted in the US (Mitchell, 2013), it was found out that an ideal and effective school usually has a 1:52 ratio for number of administrators 
against the number of students in the school. Therefore, in the community colleges under study there appears to be considerable over staffing. Again, the government may be spending a lot more money than is either normal or necessary. These figures are even more shocking, because the output or product (i.e. number of graduates) is far below normal. Ultimately, these figures reveal a considerable large and unnecessary government overspending.

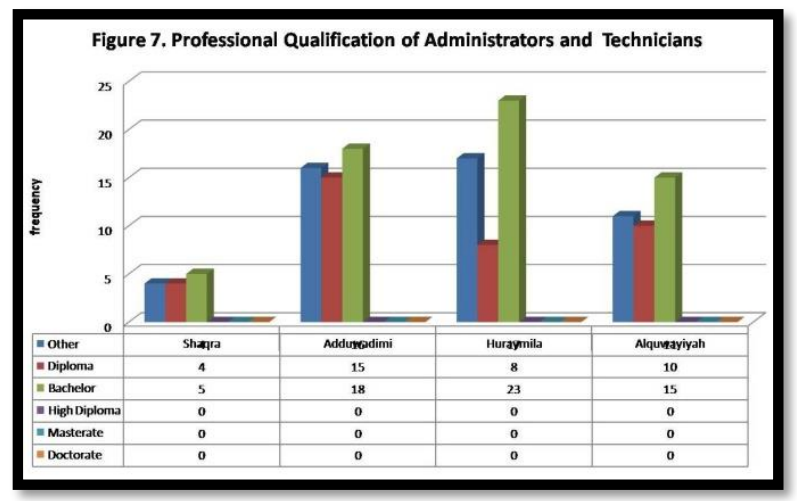

Source: Ministry of Education: Education Statistics Center (2016).

\section{Multi-Regression Analysis of Data Using SPSS ver. 20}

As table 9 reveals by displaying the $\mathrm{F}$ value $=0.754$, there is a slight positive correlation between number of enrollment, number of new entrants, and number of graduates. However, this is contradicted by the $p$ value, which is greater than 0.05 . This is perhaps due to the small number of participants involved, which suggests no statistical significance among the variables. In other words, variables such as number of enrollees and number of new entrants might not be a good predictor of the number of graduates.

Table 9 Multi-regression analysis of number of enrollments, new entrants, and graduates

\begin{tabular}{|c|c|c|c|c|c|c|}
\hline Model & & $\begin{array}{c}\text { Sum of } \\
\text { Squares }\end{array}$ & df & $\begin{array}{c}\text { Mean } \\
\text { Square } \\
\end{array}$ & $\mathbf{F}$ & Sig. \\
\hline \multirow[t]{3}{*}{1} & Regression & 11060.845 & 2 & $5530 \_423$ & .754 & $632^{a}$ \\
\hline & Residual & 7337.905 & 1 & 7337.905 & & \\
\hline & Total & 18398.750 & 3 & & & \\
\hline
\end{tabular}

a. Predictors: (Constant), NewEntrants, Enrollment

b. Dependent Variable: Grad 


\section{Summary}

The findings identified several weaknesses at the community colleges being studied, and these will be discussed below.

\section{Status of Enrollments and Graduates at the Four Community Colleges}

Enrollments in all the colleges rose and fell resulting in little increase in the three year period, 2012-2014. In terms of graduates, the top five courses producing the highest number of graduates are Computer Science, Business Banking, Human Resources, Accounting, and Marketing. Males dominated the Computer Science course, while females dominated Business Banking. The general trend however, is for more female enrollees on all the courses offered at the four community colleges. A decreasing trend in the number of graduates in the three- year period emerged. In general, the graduation rate for all four colleges was very low.

\section{Faculty Profile Faculty to Student Ratio at the Four Community Colleges}

The faculty members at the four community colleges are mainly males, most hold the rank of lecturer, and the majority are non-Saudi. Furthermore, based on the data collected, there appears to have been a continuous increase in the number of faculty members from 2012-2014. A final discovery was that, the faculty to student ratios at the community colleges are much too small.

\section{Profile of Administrators and Technicians at the Four Community Colleges}

According to the data, most of the administrators and technicians at the four community colleges hold Bachelor's degrees, and there was continuous hiring of additional administrators and technicians between 2012 and 2014. Consequently, the ratio of administrators and technicians to enrollees is considered bloated.

\section{Conclusions}

Based on the results of the documentary analyses of the four community colleges namely, Shaqra, Adduwadimi, Huraymila, and Alquwayiyah, the key findings can be summarized as follows: 
1) Enrollments at the four colleges have fallen in the past three years (2012-2014);

2) The number of graduates from the four community colleges has been steadily decreasing and shows abnormally very low graduation rates overall;

3) Ironically, despite the low number of enrollments and the low turnout of graduates, there was a continuous increase in the number of faculty members from 2012-2014;

4) The faculty member to student ratios at the community colleges are abnormally small;

5) There was continuous hiring of additional administrators and technicians across the study period, and the ratio of administrators and technicians to enrollees are also too small; and

6) The American system of community colleges is still considered the best role model for community colleges worldwide, experiencing continued success both in the U.S. and in other countries such as China, Japan, and Germany, where it is either wholly or partially adopted.

In light of this scenario, it appears that the future existence of these community colleges is uncertain. If the problems identified are not resolved by the concerned authorities the result long term may be huge financial losses or wastage on the part of the government.

\section{Recommendations}

Based on the foregoing findings of the study, the following is recommended:

1) To save the government from continuous financial losses, it is advised that the four community colleges at Shaqra University be reorganized to create two. Furthermore, if necessary, retrenchment of faculty staff and administrators must also be conducted to achieve ideal students to faculty ratios and student to administrator ratio.

2) There should be an effective and regular program put in place to disseminate information to students. The researcher learned through random interviews that some students were not clearly informed about many areas of college life, including their options after graduation.

3) To validate and confirm the findings of this present study, future researchers should conduct research that is more intensive by increasing the number of community colleges studied, collecting a greater number 
of student responses, and consulting other categories of respondents, such as faculty members, administrators, and even office staff.

\section{References}

Agodini, R., \&Dynarski, M. (2004). Are experiments the only option? A look at dropout prevention programs. Review of Economics and Statistics, 86(1), 180-194.

Al-Ghandi, S.M. (1984). A study to explore the extent to which junior colleges meet the Saudi Arabian community diverse educational needs as perceived by administrators, teachers and students. Unpublished doctoral dissertation. University of Pittsburg, USA.

Aslanian, C. B. (2001). Adult students today. New York: The College Board.

Bowen, G. A. (2009). Document analysis as a qualitative research method. Qualitative Research Journal, 9(2), 27-40.

Cohen, A. M., Brawer, F. B., \&Kisker, C. B. (2013). The American community college. Hoboken, NJ: John Wiley \& Sons.

Cristobal, S.C. Jr. \& Nahra, F.J. (2016). Challenges andopportunities for state systems of community colleges: A document analysis. Community College Journal of Research and Practice, Retrieved from: http://dx.doi.org/10.1080/10668926.2016.1142484.

Davis, B., \& Wessel, D. (1998). Prosperity: The coming 20-year boom and what it means to You. New York: Random House.

Franco, R.W. (2009). The civic role of community colleges, preparing students for the work of democracy. Retrieved fromhttp://www.compact.org/resources/downloads/CCivic rolefinal.pdf

Lee, E. W.C., \& Young, E. (2003).Pioneering the community college movement in Hong Kong. International Journal of Lifelong Education, 22(2), 47158.

Levine, A., Templin, R. G., McPhail, C., Rouecher, J. E., Shannon, H. D., \& Omundson, B. (2004). The biggest challenge for community colleges: 6 Views. Chronicle of Higher Education,Retrieved from http://chronicle.com/article/The-Biggest-Challenge-for/28226.

McCabe, R. H. (2000). No one to waste: A report to public decision-makers and communitycollege leaders. Washington, DC: Community College Press.

McVeigh, P. (2007, July). Community college: A world of opportunities. Community Colleges In the USA, 1(3). 22-27 
Mitchell, J. (2013). Is there bloat in our schools? Ratio of administrators to students.

Retrieved from http://c.ymcdn.com/sites/www.sais.org/resource/resmgr/imported/FastS tats_April.pdf.

Ministry of Education: Education Statistics Center (2016). Retrieved from: https://www.mohe.gov.sa/ar/Ministry/Deputy-Ministry-for-Planningand-Information-affairs/HESC/Ehsaat/Pa

Ministry of Higher of Education (MOHE). (2016). Retrieved from: https://www.mohe.gov.sa/en/ shu.aspx

Palinchak, R.S. (1973). The evolution of the community college. Metuchen, N.J.: Scarecrow Press

Raby, R.L. \& Valeau, E. (2009). Community Colleges in China's Two Systems. Amsterdam: Springer Press.

Yung, M. S. (2002). Community college: A newborn baby of the Hong Kong education system for the new millennium.Hong Kong Teachers' Centre Journal, 1(Spring). 35-38. 